УДК 81'42

DOI https://doi.org/10.26661/2414-1135-2021-83-35

\title{
ПЕДАГОГІЧНИЙ ДИСКУРС У ТИПОЛОГІї ДИСКУРСУ
}

\author{
Ситник I. B. \\ викладач кафедри східних мов та перекладу \\ Інститут філології \\ Київського університету імені Бориса Грінченка \\ вул. Бульварно-Кудрявська, 18/2, Київ, Україна \\ orcid.org/0000-0002-9307-6180 \\ iv.sytnyk@kubg.edu.ua
}

Ключові слова: дискурс, педагогічний дискурс, лінгвістика, текст, комунікація.
У статті на основі аналізу наукових праць досліджено місце педагогічного дискурсу в типології дискурсу. Поняття «дискурс» уважається одним із ключових понять низки гуманітарних наук. Саме через полідисциплінарність, багатозначність і багатофункціональність дискурсу не існує загальноприйнятого й однозначного визначення цього поняття, що, у свою чергу, призвело до відсутності єдиної типології дискурсу. Науковці, систематизуючи дискурс, залежно від предмета дослідження за основу використовують певний критерій або критерії та подають різні класифікації. У статті проаналізовано, виділено й систематизовано наявні основні наукові підходи до класифікації дискурсу. У результаті дослідження з'ясовано, що загальноприйнятим у парадигмі соціолінгвістичного параметра згідно з формулою спілкування «сугестор (адресант) - сугерент (адресат)» уважається розуміння педагогічного дискурсу як інституційного типу дискурсу, що характеризується певними системо-утворюючими ознаками (учасники, мета, хронотоп, стратегії, жанри). Установлено, що в лінгвістичній літературі вживається термін «педагогічний дискурс» у вузькому значенні, це означає функціонування теорії навчання й виховання, а також термін «педагогічний дискурс» у широкому значенні, тобто форма суспільної практики, яка має педагогічну мету - соціалізацію нового члена суспільства. Висвітлюються найвідоміші дослідницькі інтерпретації поняття «педагогічний дискурс» у сучасній парадигмі лінгвістичних знань. Окреслено актуальне питання еволюції поняття «педагогічний дискурс». Виділено та проаналізовано основні наукові підходи до визначення поняття «педагогічний дискурс» 3 позиції вітчизняних і закордонних дослідників. На підставі аналізу наукових праць із різними підходами до визначення поняття «педагогічний дискурс» запропоновано авторську дефініцію цього поняття, яка трактується як систематичний процес взаємодії мовців у межах педагогічної ситуації, де учасники спілкування використовують екстралінгвістичні, прагмалінгвістичні та лінгвістичні знакові системи. 


\title{
PEDAGOGICAL DISCOURSE IN DISCOURSE TYPOLOGY
}

\author{
Sytnyk I. V. \\ Lecturer at the Department of Oriental Languages and Translation \\ Institute of Philology \\ of Borys Hrinchenko University of Kyiv \\ Bulvarno-Kudriavska str, 18/2, Kyiv, Ukraine \\ orcid.org/0000-0002-9307-6180 \\ iv.sytnyk@kubg.edu.ua
}

Key words: discourse, pedagogical discourse, linguistics, text, communication.
This paper calls into question on the pedagogical discourse in the framework of discourse typology. It is generally accepted that the concept of «discourse» is widely considered to be multidisciplinary, because it is the research subject in a number of humanities. In the literature there seems to be no general definition of "discourse", thus it is commonly investigated. Depending on the subject of research, each scholar defines the term "discourse" in his own way. The central discourse typology has not been established yet. The existing scientific approaches to the classification of discourse are determined and investigated. As a result of the research it was found that in the paradigm of sociolinguistic parameter pedagogical discourse is interpreted as an institutional type of discourse characterized by certain system-forming features (participants, purpose, strategies, genres etc.). It is identified that in the linguistic literature the term "pedagogical discourse" is defined as teaching and education theories functioning. Other researchers would seem to suggest that there may be other possible explanations of the term "pedagogical discourse". In general terms, "pedagogical discourse" is generally understood to mean a social practice that has a pedagogical purpose - socialization. This paper has underlined the most widespread research interpretations of the concept of "discourse" within modern linguistic paradigm. The concept of "discourse" evolution is stated. The existing main scientific approaches to the definition of "discourse" from the standpoint of domestic and foreign researchers are examined, introduced and discussed. A recent review of the literature on this topic found that there is no clear definition of "pedagogical discourse". Given that our definition of "pedagogical discourse" is based on the results from such analyses. The author's definition of "pedagogical discourse" is proposed, which is defined as a systematic process of speaker interaction within the pedagogical situation, where participants use extralinguistic, pragmalinguistic and linguistic sign systems.
Постановка проблеми. У сучасній науковій літературі існують підходи до класифікації дискурсу, що базуються на різних критеріях. Важливим для дослідження $\epsilon$ питання визначення місця педагогічного дискурсу в типології дискурсу. Типологію дискурсу розглядали як зарубіжні (В. Карасик, Н. Нікульшин, О. Ревізіна, Г. Солганник, М. Фуко, Й. Хабермас), так і вітчизняні (Ф. Бацевич, А. Загнітко, О. Кучерова, Г. Почепцов, К. Серажим, О. Станкевич, О. Христенко, Г. Яворська) дослідники. Зазначимо, що сьогодні не існує єдиної класифікації, тому що науковці, класифікуючи дискурс залежно від того, який критерій чи які категорії $є$ важливими для їхнього напряму дослідження, для потреб конкретного аналізу, беруть за основу різі ознаки та подають різноманітні класифікації. Як результат на сучасному етапі розвитку наукової думки в галузі дискурсології створити загальну типологію дискурсів практично неможливо, можна лише узагальнити основні підходи до їх класифікації. Актуальність дослідження зумовлена відсутністю єдиної загальновживаної типології дискурсу, що, у свою чергу, призвело до появи різних підходів до інтерпретації педагогічного дискурсу.

Мета статті полягає в установленні сутності й ознак педагогічного дискурсу в лінгвістиці за допомогою систематизації та характеристики класифікацій дискурсу.

До завдань розвідки належать установлення сутності поняття «педагогічний дискурс», визначення та характеристика класифікації дискурсу, 
3'ясування місця й основних ознак педагогічного дискурсу в типології дискурсу.

Об'єктом дослідження є педагогічний дискурс.

Предмет дослідження становлять ознаки педагогічного дискурсу в типології дискурсу.

Виклад основного матеріалу дослідження. У лінгвістичних дослідженнях останніх років дискурс класифікуюсь на основі різних критеріїв залежно від предмета дослідження.

Так, А. Кібрик як критерії для класифікації дискурсів висуває модус (канал передачі інформації), категорію формальності, жанр, функціональний стиль. Через канал передачі інформації виділяють усний і письмовий дискурси $[1$, с. 6]. За сферою і середовищем спілкування виділяють побутовий, науковий, політичний, діловий, конфесійний [2, с. 15]. За національно-лінгвокультурними параметрами дискурс поділяють на англійський дискурс, український дискурс, іспанський дискурс тощо [3, с. 68].

Розглянемо детальніше типологію українського науковця Г. Почепцова. Його типологія створена на основі кількох критеріїв: особливостей мовлення в контексті певного дискурсу, особливостей знакового (символічного) відображення реальної ситуації (у зіставленні з базовою комунікативною ситуацією - звичайним спілкуванням обох осіб у ситуації безпосереднього контакту). За цими ознаками науковець виділяє радіо- й теледискурс, фольклорний, газетний, театральний візуальний, літературний, рекламний, педагогічний, політичний, релігійний, офіційний, міфологічний, іронічний, святковий, невербальний, міжкультурний, неправдивий дискурс, кінодискурс, дискурс у сфері PR [4, с. 112].

Український лінгвіст Ф. Бацевич на основі комунікативної моделі Р. Якобсона класифікує дискурс за такими ознаками [5, с. 73]:

- за виявом комунікації в суспільстві дискурс може визначатися як комунікативний, мовний; вербальний, невербальний, сучасні дискурсивні практики, дискурс мовчання;

- за каналами спілкування: візуальний, слуховий, тактильний;

- за різновидами мовлення (формами мовленнєвої діяльності): усний, письмовий;

- за типами й формами мовлення, принципами побудови повідомлення: монологічний, діалогічний, наративний, риторичний, іронічний;

- за тотожністю $з$ предметом дослідження різних наук: соціологічний, політологічний, філологічний;

- за індивідуальними характеристиками мовлення: особистісний, неповторний, колективістський, авторитарний;

- за реалізацією в різних сферах спілкування: юридичний, політичний, газетний, кінодискурс, театральний, рекламний, святковий;
- за етнокультурними особливостями спілкування: міжкультурний, різномовний;

- за функціональним стилем: науковий, діловий, художньо-белетристичний;

- за виявом правил спілкування, способів викладу й утілення прагматичної мети мовців: етикетний, лайливий, дидактичний.

А. Бєлова запропонувала класифікацію дискурсів 3 урахуванням двох основних чинників: характеру комунікації і сфер функціонування. За характером комунікації - офіційний, неофіційний, спонтанний, підготовлений, чоловічий, жіночий, дитячий, дискурс підлітків, людей похилого віку, конфліктний, авторитарний, лайливий. За сферами комунікації виділені такі типи дискурсу: академічний, педагогічний, рекламний, релігійний, бізнес-дискурс, дипломатичний, переговорів, політичний, риторичний, сімейного спілкування, юридичний, Інтернет-дискурс, медичний, психотерапія/НЛП [6, с. 92].

За сферою спілкування А. Баранов і Ю. Караулов розрізняють політичний, юридичний, військовий, економічний, педагогічний та інші види. Окремим різновидам дискурсу присвячували дослідження багато вчених, наприклад: Н. Волкогон - рекламному, А. Габідулліна - навчально-педагогічному, Л. Колток - педагогічному, С. Коновець - газетному, К. Серажим - політичному, Т. Скуратовська - судовому, I Соболєва - публіцистичному тощо [7, с. 37].

Варто також зазначити, що лінгвісти часто пов'язують дискурс 3 певною лінгвокультурою: американський дискурс (С. Пак), англійський дискурс (Е. Селіванова) тощо. Тип дискурсу може визначатися й гендерними параметрами (О. Прокудіна) [8, с. 47-59].

Російський мовознавець В. Карасик у науковій праці «Про типи дискурсу» класифікує дискурс 3 позиції соціолінгвістики й виділяє два головні його типи: персональний (індивідуально-орієнтований) та інституційний (статусно-орієнтований) [9, с. 5-20]. У цій класифікації дискурс визначається прийнятими в суспільстві сферами спілкування i сформованими інститутами. У першому типі мовець виступає як особистість зі своїм багатим внутрішнім світом, а в другому - як представник тієї або іншої соціальної групи [9, с. 5-20]. Інституційний дискурс мовознавець розділяє на науковий, військовий, політичний, адміністративний, сценічний діловий, спортивний і масово-інформаційний. Під інституційним дискурсом В. Карасик розуміє особливий різновид спілкування, знайомих або незнайомих, людей один із одним із використанням регулярно повторюваних у певних умовах і контекстах мовних зворотів, тобто кліше [9, с. 5-20].

Згідно з дослідженнями М. Олешкова, інституційному дискурсу об'єктивно притаманні такі 
системоутворювальні ознаки, як «статусно-кваліфіковані учасники, локалізований хронотоп, конвенціонально обумовлена в рамках цього соціального інституту мета, ритуально зафіксовані цінності, інтенціонально «закріплені» стратегії (послідовності мовних дій у типових ситуаціях), обмежена номенклатура жанрів і жорстко обумовлений арсенал прецедентних феноменів (імен, висловлювань, текстів і ситуацій)» [10, с. 92].

Отже, узагальнюючи висновки науковців, констатуємо, що педагогічний дискурс належить до інституційного типу дискурсу, володіє всіма вказаними вище системоутворювальними ознаками $і$ співвідноситься 3 юридичним, науковим, рекламним, релігійним, спортивним, військовим тощо $[11$, с. 132].

Педагогічний дискурс почали системно досліджувати після активізації досліджень у галузі педагогічної лінгвістики (англ. Educational linguistics), що як самостійна галузь вивчення виникла в середині 70-х років минулого століття завдяки роботі Б. Сполські [12]. Він був першим, хто запропонував цей термін у 1972 році в доповіді на третьому з'ізді Міжнародної асоціації прикладної лінгвістики. У праці «Educational Linguistics: An Introduction» Б. Сполські тлумачить педагогічну лінгвістику (термін, запозичений із педагогічної психології й педагогічної соціології) як модель, що випливає 3 теорії мови, теорії вивчення (психологіï), теорії вивчення мови (психолінгвістики), 3 використання мови (соціолінгвістики), і все це спрямовано до педагогіки навчання другої мови (англ. second language pedagogy).

Поділяє погляди Б. Сполські шведський лінгвіст Франсіс М. Хульт, який у спільній науковій праці «The Handbook of Educational Linguistics» стверджує, що педагогічна лінгвістика - «галузь дослідження, яка інтегрує дослідницькі засоби лінгвістики й інших суміжних дисциплін соціальних наук 3 метою цілісного дослідження широкого кола питань, пов'язаних із мовою та освітою» [12]. Дещо інші думки висловлює англійський лінгвіст М. Холлідей. Він стверджує, що існують дві дисципліни: педагогіка й лінгвістика, які об'єднуються в процесі взаємодії і призводять до деякої нової площини досліджень, де вже немає цих двох об'єктів, а є тільки один - педагогічна лінгвістика, процес вивчення мови учнем і навчання мови вчителем, процес успішного обміну інформацією між учнем і вчителем [13, с. 354-358].

У 70-ті роки представники Бірмінгемської школи дискурс-аналізу Д. Синклер та М. Кулхардт [14] використали метод дискурс-аналізу для вивчення педагогічного спілкування і здійснили масштабне дослідження, предметом якого стала лінгвістична взаємодія вчителя й учня в класі. Дослідники вперше використовують поняття «педагогічний дискурс» $\mathrm{i}$ розглядають його як ситуативно й соціально визначену мовленнєву діяльність між учителем та учнями [14]. Вивчаючи мовленнєву взаємодію учнів і вчителів на уроках, Д. Синклер та М. Култхард охарактеризували зв'язки між висловлюваннями в потоці мовлення, а також функції висловлювань і способи їх інтерпретацій, хто і як керує ходом спілкування, як змінюються ролі мовця і слухача та реалізується їхнє право на мову, як уводяться нові теми й закономірності їхнього розвитку.

У країнах СНД основні ідеї педагогічної лінгвістики перейняла педагогічна риторика, у якій вивчається спілкування в процесі викладання й виховання. Наголосимо на тому, що перші дослідження педагогічного дискурсу в країнах СНД відбувалися саме в межах педагогічної риторики. Педагогічний дискурс трактується як процес мовної поведінки вчителя на уроці та складається з вербальної поведінки, гучності, висоти тону, темпу, ритму, жестів, міміки, пози, знакове використання простору під час мовної поведінки (А. Михальська, Т. Ладиженська, Л. Антонова, О. Філіпова, А. Мурашов, В. Русецький, Н. Антонова).

Н. Антонова розглядає педагогічний дискурс як один із інституційних видів дискурсу, наголошує, що він являє собою спілкування, яке характеризується певними стратегіями й тактиками в рамках статусно-рольових відносин між учителем та учнем [15, с. 35-49].

Дослідниця А. Михальська розуміє під педагогічним дискурсом мовну поведінку в тому виді комунікативних ситуацій, для яких природа комунікативної події визначається як «навчання й виховання в професійній та освітній діяльності» [16, с. 86].

Як процес спільної діяльності учасників освітнього процесу, який має педагогічну мету, розглядає педагогічний дискурс дослідниця Т. Єжова. На думку дослідниці, для педагогічного дискурсу характерними є такі властивості: динамічність, соціальність, інтегративність, персоналізація, діалогічність, контекстуальність, цілісність, когерентність, ситуативна обумовленість, інтенціональність. Щодо функцій педагогічного дискурсу Т. Єжова зазначає, що він включає всі базові функції педагогічної діяльності, а саме: трансляцію соціального досвіду, комунікативну, регулятивну, креативну, аксіологічну, культуротворчу, інтеркультурну комунікацію [17, с. 54].

В. Карасик характеризує мету, тактику та стратегіi, хронотоп, цінності, дискурсивні формули й жанри педагогічного дискурсу. Дослідник відносить педагогічний дискурс до різновиду інституційного типу дискурсу і трактує як форму «суспільної практики», як спілкування в рамках статусно-рольових відносин. Метою педагогічного дискурсу, на думку В. Карасика, є соціалізація 
нового члена суспільства. Для досягнення поставленої мети реалізуються стратегії, що складаються 3 комунікативних інтенцій. Порівняно 3 іншими дискурсами педагогічний дискурс відрізняється нерівністю основних учасників спілкування (учителя й учня). Хронотоп педагогічного дискурсу навчальний заклад, школа, університет, навчальна аудиторія і спеціально відведений час для цього виду спілкування (урок, лекція, іспит). Що стосується цінностей педагогічного дискурсу, то вони можуть бути виражені аксіологічними протокольними реченнями [18, с. 63].

Терміном «педагогічний дискурс» користуються як філологи, так і педагоги. У педагогіці, як правило, розвивають структуру та схему педагогічного дискурсу й ефективні методики викладання, тоді як у філології досліджуються лінгвістичні аспекти мовлення в процесі навчання та характеристики текстів, які беруть участь у цій схемі [19, с. 45-49].

Нині немає єдиного розуміння та дефініції поняття «педагогічний дискурс». Нами проаналізовано праці вчених, присвячені тлумаченню цього поняття, які засвідчують, що педагогічний дискурс визначають як спілкування, що характеризується певними стратегіями й тактиками, у рамках статусно-рольових відносин між учителем та учнем, відповідно, викладачем і студентом [15]; форму «суспільної практики» [18, с. 63]; певну об'єктивно існуючу систему ціннісно-смислової комунікації суб'єктів освітнього процесу, що функціонує в освітньому середовищі вишів [20, с. 84-87], взаємодію сторін у межах комунікативної ситуації, як поточну мовну діяльність, яка обслуговує комунікативну сферу, що виникає в результаті цієї діяльності й реалізуються за допомогою вербальних і невербальних знаків текстів, що мають певну структуру, жанрові особливості й особливий тезаурус [21]; процес спільної діяльності учасників освітнього процесу, який має педагогічну мету соціалізацію нового члена суспільства [17].

Виділимо найважливіші характеристики педагогічного дискурсу, представлені в науковій літературі різними авторами, а саме:

- своєрідна суспільна мета (соціалізація члена суспільства);

- хронотоп (єдність часу й місця);

- учасники (учителі й учні, викладачі та студенти);

- особливі цінності, що формують світогляд студента;

- жанрова парадигма педагогічного дискурсу: урок, лекція, семінар, іспит, батьківські збори, бесіда батьків і дитини, учителя й учня тощо;

- жанри педагогічного спілкування (пояснення, вправа, контроль, організація діяльності основних учасників);
- своєрідні тексти (прислів’я, приказки, тексти підручників тощо); тегій.

- характерне використання педагогічних стра-

У межах педагогічного дискурсу виділяють підтипи. Так, дискурс, що міститься в підручниках, навчальних посібниках, визначають як дидактичний. Його також називають і «педагогічним», «навчальним», «навчально-педагогічним» дискурсом. Ми переконані, що поняття «педагогічний дискурс»є ширшим поняттям, яке може бути за певних умов конкретизовано поняттями «дидактичний дискурс» (дискурс функціонування теорії навчання й виховання), «навчально-дидактичний», «навчальний дискурс» (дискурс процес передачі й засвоєння знань, умінь і навичок) тощо [7, с. 37].

Висновки й перспективи подальших розробок. Аналіз наукових праць 3 типології дискурсу дав можливість визначити сутність поняття «педагогічний дискурс» і встановити його основні ознаки. Таким чином, можна констатувати, що педагогічний дискурс - систематичний процесу взаємодії мовців у межах педагогічної ситуації, де учасники спілкування використовують екстралінгвістичні, прагмалінгвістичні та лінгвістичні знакові системи. Педагогічний дискурс, незважаючи на значну кількість праць, присвячених дослідженню його структури, характеристик, досі залишається дискусійним питанням як у структурному, так і функційному відношеннях. Відкритим також залишається питання розмежування понять «педагогічний», «навчальний», «навчально-педагогічний» дискурс.

\section{ЛІТЕРАТУРА}

1. Кибрик А.А. Модус, жанр и другие параметры классификации дискурсов. Bonpocbl языкознания. 2009. № 2. С. 3-21.

2. Валгина Н.С. Теория текста. Москва : Логос, 2003. $173 \mathrm{c}$.

3. Ревзина О.Г. Дискурс и дискурсивные формации. Критика и семиотика. 2005. № 8. C. 66-78.

4. Почепцов Г. Теория коммуникации. Москва : Рефл-бук, 2001. 656 с.

5. Бацевич Ф.С. Основи комунікативної лінгвістики : навчальний посібник. Київ : ВЦ. «Академія», 2004. 344 с.

6. Белова А.Д. Лингвистические аспекты аргументации. Київ : Київ. нац. ун-т імені Тараса Шевченка, 1997. 300 с.

7. Нікітіна А.В. Педагогічний дискурс учителя словесника : монографія. Київ : Ленвіт, 2013. 338 c.

8. Габідулліна А.Р. Навчально-педагогічний дискурс: категоріальна структура та жанрова 
своєрідність : дис. ... докт. філ. наук : 10.02.02. Донецьк : ДНУ, 2009. С. 47-59.

9. Карасик В.И. О типах дискурса. Языковая личность: институциональный и персональный дискурс. 2000. С. 5-20.

10. Олешков М.Ю. Основы функциональной лингвистики: дискурсивный аспект : учебное пособие. Нижний Тагил, 2006. 146 с.

11. Селіванова О.О. Сучасна лінгвістика: термінологічна енциклопедія. Полтава : Довкілля, 2006. $716 \mathrm{c}$.

12. Bernard Spolsky, Francis M. Hult. The handbook of educational linguistics. Blackwell Publishing, 2008. $675 \mathrm{p}$.

13. Halliday M.A.K. On the concept of "Educational linguistics". Language and Education. 2007. P. 354-358.

14. Sinclair J.M., Coulthard R.M. Towards an Analysis of Discourse The English Used by Teachers and Pupils. London : Oxford University Press, 1975. $163 \mathrm{p}$.

15. Антонова Н.А. Педагогический дискурс: речевое поведение учителя на уроке : дисс. ... канд. фил. наук : 10.02.01. Саратов : Сарат. гос. ун-т им. Н.Г. Чернышевского, 2007. С. 35-49.

16. Михальская А.К. Педагогическая риторика: история и теория : учебное пособие. Москва : Академия, 1998. $432 \mathrm{c.}$

17. Ежова Т.В. К проблеме изучения педагогического дискурса. Вестник ОГУ. 2006. № 2. C. 54.

18. Карасик В.И. Характеристики педагогического дискурса. Языковой круг: личность, кониелтыл, дискурс. 1999. С. 63.

19. Александрова В.Ф. Навчальний текст у рамках педагогічного дискурсу. Матеріали VI Міжнародної науково-практичної інтернет-конферениії. 2015. С. 45-49.

20. Суворова С.Л. Феноменология исследования понятий «дискурс» и «педагогический дискурс». Вестник Южно-Уральского государственного университета. 2012. № 4. С. 84-87.

21. Олешков М.Ю. Моделирование коммуникативного процесса : монография. Нижний Тагил : Нижнетагильская гос. соц.-пед. академія, 2006. 336 с.

\section{REFERENCES}

1. Kibrik A.A. Mode, genre and other parameters of the classification of discourses [Modus, zhanr i drugiye parametry klassifikatsii diskursov.]. Questions of linguistics. 2009. № 2. pp. 3-21.

2. Valgina NS Text theory [Teoriya teksta]. Moscow: Logos, 2003. 173 p.

3. Revzina O.G. Discourse and discursive formations [Diskurs i diskursivnyye formatsii]. Criticism and semiotics. 2005. № 8. pp. 66-78.
4. Pocheptsov G. Theory of communication [Teoriya kommunikatsii]. Moscow: Refl-book, 2001. $656 \mathrm{p}$.

5. Batsevich F.S. Foundations of Communicative Linguistics [Osnovy komunikatyvnoyi linhvistyky] : Navch. posib. Kiev : VTs. "Academy", 2004. $344 \mathrm{p}$

6. Belova A.D. Linguistic aspects of argumentation [Lynhvystycheskye aspekty arhumentatsyy]. Kyiv : Kyiv. nat. Taras Shevchenko University, 1997. $300 \mathrm{p}$

7. Nikitina A.V. Pedagogical discourse of a teacher of language and literature [Pedahohichnyy dyskurs uchytelya slovesnyka] : monograph. Kiev : Lenvit, 2013. 338 p.

8. Gabidullina A.R. Initial pedagogical discourse: categorical structure and genre [Navchalnopedahohichnyy dyskurs: katehorialna struktura ta zhanrova svoyeridnist]: dis. ... PhD : 10.02.02. Donetsk: DNU, 2009. pp. 47-59.

9. Karasik V.I. On the types of discourse [O tipakh diskursa.]. Linguistic personality: institutional and personal discourse. 2000. pp. 5-20.

10. Oleshkov M.Y. Fundamentals of functional linguistics: discursive aspect [Osnovy funktsional'noy lingvistiki: diskursivnyy aspekt] : textbook. Nizhniy Tagil, 2006. 146 p.

11. Selivanova O.O. Modern linguistics: terminological encyclopedia [Suchasna linhvistyka: terminolohichna entsyklopediya]. Poltava : Dovkilla, 2006.716 p.

12. Bernard Spolsky, Francis M. Hult. The handbook of educational linguistics. Blackwell Publishing, 2008. $675 \mathrm{p}$

13. Halliday M.A.K. On the concept of "Educational linguistics". Language and Education. 2007. pp. 354-358.

14. Sinclair, J.M., \& Coulthard, R. M. Towards an Analysis of Discourse The English Used by Teachers and Pupils. London : Oxford University Press, 1975. 163 p.

15. Antonova N.A. Pedagogical discourse: speech behavior of the teacher in the lesson [Pedagogicheskiy diskurs: rechevoye povedeniye uchitelya na uroke]: dis. ... can. phil. : 10.02.01. Saratov: Saratov. state Univ. N.G. Chernyshevsky, 2007. pp. 35-49.

16. Mikhalskaya A.K. Pedagogical rhetoric: history and theory [Pedagogicheskaya ritorika: istoriya i teoríya]: textbook. Moscow : Academy, 1998. $432 \mathrm{p}$.

17. Ezhova T.V. To the problem of studying pedagogical discourse [K probleme izucheniya pedagogicheskogo diskursa]. OSU bulletin. 2006. № 2. pp. 54-65.

18. Karasik V.I. Characteristics of pedagogical discourse [Kharakteristiki pedagogicheskogo 
diskursa]. Language circle: personality, concepts, discourse. 1999. pp. 63-80.

19. Alexandrova V. F. Educational text within the pedagogical discourse [Navchalnyy tekst u ramkakh pedahohichnoho dyskursu]. VI International Scientific and Practical Internet Conference. 2015. pp. 45-49.

20. Suvorova SL Phenomenology of the study of the concepts of "discourse" and "pedagogical discourse" [Fenomenologiya issledovaniya ponyatiy "diskurs" i "pedagogicheskiy diskurs"]. Bulletin of the South Ural State University. 2012. № 4. pp. 84-87.

21. Oleshkov M. Y. Modeling of communicative process [Modelirovaniye kommunikativnogo protsessa] : monograph. Nizhny Tagil : Nizhny Tagil state. soc.-ped. Academy, 2006. 336 p. 